\title{
REVIEW
}

\section{Sonidegib: Safety and Efficacy in Treatment of Advanced Basal Cell Carcinoma}

\author{
Alessia Villani - Gabriella Fabbrocini - Claudia Costa • \\ Massimiliano Scalvenzi
}

Received: March 17, 2020 / Published online: April 15, 2020

(C) The Author(s) 2020

\section{ABSTRACT}

Hedgehog inhibitors are promising alternative treatments for patients with advanced basal cell carcinomas. Sonidegib $\left(\right.$ Odomzo $\left.^{\circledR}\right)$, an oral smoothened (SMO) antagonist, is indicated for the treatment of adult patients with locally advanced basal cell carcinoma (laBCC) who present recurrence following surgery or radiation therapy, or those who are not candidates for surgery or radiotherapy. Several studies and randomized controlled trials have been conducted to evaluate the efficacy, safety, and tolerability of this new molecule that has demonstrated a good response rate (44\%). Grade 1-2 adverse events have also been repor- ted. Further studies of real-world experiences are needed to better understand the correct management of the drug, alternative dosing regimens, and differences with other hedgehog inhibitors. This article provides a complete overview of the pharmacology and pharmacokinetics of sonidegib and a report of the trials and studies conducted. The most frequent adverse events and their correct management are also discussed.

Keywords: Adverse events; Basal cell carcinoma; Hedgehog inhibitors; Sonidegib

Enhanced Digital Features To view digital features for this article go tohttps://doi.org/10.6084/m9.figshare. 12086673.

\author{
A. Villani $(\bowtie) \cdot$ G. Fabbrocini $\cdot$ C. Costa . \\ M. Scalvenzi \\ Dermatology Unit, Department of Clinical Medicine \\ and Surgery, University of Naples Federico II, \\ Naples, Italy \\ e-mail: ali.vil@hotmail.it
}




\section{Key Summary Points}

\section{Why carry out this study?}

Hedgehog inhibitors (HHI) are promising alternative treatments for patients with advanced basal cell carcinomas. Sonidegib $\left(\right.$ Odomzo $\left.{ }^{\circledR}\right)$, an oral smoothened (SMO) antagonist, is indicated for the treatment of adult patients with locally advanced basal cell carcinoma.

Several studies and randomized controlled trials have been conducted to evaluate the efficacy, safety, and tolerability of this new molecule.

\section{What was learned from the study?}

Preclinical studies have shown the high tissue penetration, the good oral bioavailability, and the high volume of distribution of this molecule.

A 42-month analysis of the randomized BOLT study confirmed the long-term efficacy and safety of sonidegib; the objective response rate (ORR) observed for patients with locally advanced basal cell carcinoma (laBCC) was 56.1\% (95\% CI 43.3-68.3\%) and $46.1 \%$ (95\% CI $37.2-55.1)$ for the $200 \mathrm{mg}$ and $800 \mathrm{mg}$ groups, respectively.

To ensure maximum benefit from therapy, further studies of real-world experiences to better understand the correct management of the drug, alternative dosing regimens, and differences with other HHI are needed.

\section{INTRODUCTION}

Basal cell carcinoma (BCC) is the most common form of skin cancer with increasing worldwide incidence, accounting for $80 \%$ of nonmelanoma skin cancer cases. More than 2.8 million new cases of BCC are diagnosed each year in the USA and contribute to over 3000 deaths $[1,2]$. Although it has low risk of metastasis, it is a slow-growing tumor that causes morbidity, via its usual proximity to critical facial structures, and lowers patients' quality of life. It also has a tendency to relapse, occur in multiple locations, and invade and destroy local tissues [3-5]. BCCs are classified according to prognostic factors, including tumor size, location, histologic characteristics, margins, and rate of recurrence. The majority of them can be treated with surgical excision, resulting in 5-year cure rates of up to $90 \%$. Alternative treatment options include electrodesiccation, cryotherapy, curettage, photodynamic therapy, and the use of topical imiquimod or 5-fluorouracil treatment $[6,7]$. Rarely, these tumors can progress invading the surrounding structures locally or metastasizing, resulting in advanced BCCs [8]. This group include locally advanced BCC (laBCC) and metastatic BCC (mBCC). Surgery and radiotherapy are often not viable options for advanced BCCs, supporting the need for alternatives. Inhibition of the hedgehog (Hh) signaling pathway is among the few treatment options available for patients with advanced BCCs $[9,10]$. The Hh signaling pathway is a key regulator of cell growth and differentiation during embryonic development, but it is mostly silenced in adults, with only limited activity in some processes, including hair growth and maintenance of taste. Mutations in the human homologs of Drosophila patched (PTCH1), smoothened (SMO), and suppressor of fused (SUFU), resulting in aberrant hedgehog signaling pathway, have been detected in patients with Gorlin syndrome (also known as nevoid BCC syndrome) as well as in over 95\% of patients with sporadic BCCs [11]. Thus, recent studies have focused on developing therapeutic strategies that deactivate the $\mathrm{Hh}$ signaling pathway by inhibiting SMO receptor. The discovery of receptor-targeted molecules in the $\mathrm{Hh}$ pathway have led to the approval of two hedgehog pathway inhibitors (HPIs): vismodegib and sonidegib [12-15]. Vismodegib was EMA-approved for the treatment of laBCC and symptomatic metastatic BCC based on outcome from the ERIVANCE study. Sonidegib, which is 
newer to the market, was EMA-approved for the treatment of laBCC based on the results of the BOLT study. Although, these two molecules act on the same pathway, there are currently no evidence-based recommendations to help clinicians choose between them. The aim of this article is to provide a complete overview of the pharmacokinetics, efficacy, and safety of sonidegib in patients with laBCCs. This article is based on previously conducted studies and does not contain any studies with human participants or animals performed by any of the authors.

\section{THE HEDGEHOG PATHWAY IN BASAL CELL CARCINOMA}

The Hh signaling pathway plays a pivotal role in many processes such as organogenesis, patterning, proliferation, survival, and differentiation. It is usually silenced in most adult tissues. The Hh pathway can be stimulated by three $\mathrm{Hh}$ ligands [Sonic Hh (Shh), Indian (Ihh), or Desert (Dhh)]; however, Shh is the most widely expressed and also the most potent of these ligands [11]. When these ligands bind to patched (PTCH), a protein that acts as a repressor of the pathway, the inhibition of smoothened (SMO) by PTCH is relieved, thus resulting in activation of SMO signaling. The activation of SMO also decreases the interaction between suppressor of fused homolog (SUFU) and glioma-associated oncogene (GLI) proteins, which allows GLI proteins to enter the nucleus and bind transcriptional targets to regulate cellular gene expression. Aberrant activation of the Hh pathway have been implicated in the pathogenesis of different cancers, included basal cell carcinoma. Thereby, new molecules targeting SMO, thus interrupting the $\mathrm{Hh}$ signaling pathway, have been developed to treat the majority of advanced BCCs $[16,17]$.

\section{SONIDEGIB: A NOVEL INHIBITOR OF THE HH PATHWAY}

Sonidegib under the trade name Odomzo was approved in July 2015 by the Food and Drugs
Administration (FDA) and is available in $200 \mathrm{mg}$ capsules for patients aged $\geq 18$ years with laBCC who present recurrence following surgery or radiation therapy or those who are not candidates for surgery or radiotherapy [14]. The European Commission also approved sonidegib in August 2015 for the same indications [15] (Table 1). Sonidegib is contraindicated in women who are either pregnant or breast-feeding as it may cause death or severe birth defects in developing fetus, as hedgehog signaling plays a pivotal role in early embryogenesis [14].

\section{Pharmacodynamics and Pharmacokinetics}

Sonidegib (LDE-225) is an orally available small molecular inhibitor of the hedgehog pathway. It acts by binding to and inhibiting the activity of the SMO transmembrane protein, resulting in complete suppression of GLI and tumor regression [18]. In vitro studies and in animal models have demonstrated the inhibition of $\mathrm{Hh}$ signaling and the antitumor activity of sonidegib; the oral administration of sonidegib in mouse models resulted in complete suppression of glioma-associated oncogene homolog 1 (GLI1) and tumor regression, suggesting targeted inhibition of hedgehog signaling $[19,20]$. Several preclinical studies have shown the high tissue penetration, including blood and brain barrier, and good oral bioavailability of this molecule [21]. In 2014, a first-in-human doseescalation phase I study with 103 adult patients with advanced solid tumors treated with sonidegib showed that there was dose- and exposure-dependent inhibition of GLI1 mRNA expression in tumor and normal skin biopsies. The maximum tolerated dose was determined to be $800 \mathrm{mg}$ daily and $250 \mathrm{mg}$ twice daily after testing doses ranging from 100 to $3000 \mathrm{mg}$ daily and from 250 to $750 \mathrm{mg}$ twice daily. No advantages were seen with twice-daily dosing [22]. These parameters were also confirmed in the phase II BOLT trial, in which, for patients treated with sonidegib $200 \mathrm{mg}$ for laBCC who had valid biomarker samples $(n=55$ at week 9 and $n=48$ at week 17), the median percentage from baseline in GLI1 expression levels was 
Table 1 Characteristics of sonidegib $[14,15]$

\begin{tabular}{|c|c|}
\hline Name & Sonidegib (Odomzo) \\
\hline $\begin{array}{l}\text { Class; mechanism of } \\
\text { action }\end{array}$ & Antineoplastic; smoothened protein inhibitor \\
\hline \multirow[t]{2}{*}{ Date of approval } & FDA: July 2015 \\
\hline & EMA: August 2015 \\
\hline Treatment & Inoperable laBCC in patients aged $\geq 18$ years \\
\hline Dosage & $200 \mathrm{mg} /$ day oral capsule \\
\hline Pharmacokinetics & $\begin{array}{l}\text { Estimated } 6 \% \text { oral bioavailability; highly bound to human plasma proteins; high volume of } \\
\text { distribution }\end{array}$ \\
\hline \multirow[t]{3}{*}{ Pharmacodynamics } & GLI levels $\downarrow$ \\
\hline & GLI controlled transcription $\downarrow$ \\
\hline & Cellular proliferation $\downarrow$ \\
\hline Adverse events & $\begin{array}{l}\text { Muscle spasms, alopecia, dysgeusia, fatigue, nausea, musculoskeletal pain, diarrhea, decreased } \\
\text { weight, decreased appetite, myalgia }\end{array}$ \\
\hline $\begin{array}{l}\text { Most important trial for } \\
\text { approval }\end{array}$ & BOLT phase II trial \\
\hline
\end{tabular}

$-91.07 \%$ at week 9 and $-93.75 \%$ at week 17 (both $p<0.0001$ versus baseline) [23]. Moreover, the greatest reductions from baseline were observed in patients who had disease control, in line with the Hh pathway inhibition. Sonidegib has an absorption rate of $<10 \%$ upon oral administration, even though, with a high-fat meal, the absorption increases 7.4-7.8-fold. It is characterized by a high volume of distribution (>9000 L), indicating high distribution in the tissues [21]. Consequently, the concentration of sonidegib is six times higher in skin than in plasma. Sonidegib has a relatively long half life of 28 days due to its protein-binding capacity (>97\%) with a median time to peak concentration (Tmax) of $2-4 \mathrm{~h}$. The steady state is reached approximately after 4 months from the initial dosing. For these reasons, sonidegib is administered at the dosage of $200 \mathrm{mg}$ daily via oral administration on empty stomach $[22,24,25]$.

\section{Metabolism and Drug Interaction}

Sonidegib is metabolized in the liver, via oxidation and amide hydrolysis by the cytochrome P450 (CYP) enzyme CYP3A4, so that the main circulating compound is unchanged sonidegib $(36 \%)$ and the circulating metabolites (45\%). Sonidegib and its metabolites are excreted via the feces (93\%) with $2 \%$ recovered in the urine. Finally, based on pharmacokinetics studies, no dose adjustment is needed for mild and moderate renal impairment, mild hepatic impairment, gender, age, weight, or ethnicity when using sonidegib $[14,15]$. Indeed, coadministration of sonidegib with strong or moderate inhibitors of CYP3A4, causing an increase in plasma exposure, should be avoided. If required, the moderate CYP3A inhibitor should be administered for $<14$ days and patients monitored closely for adverse events, in particular musculoskeletal events, whereas coadministration of sonidegib with strong and moderate CYP3A inducers may decrease the plasma exposure to sonidegib; if necessary, dosage 
increase to $400-800 \mathrm{mg}$ sonidegib once daily should be considered $[15,26,27]$.

\section{CLINICAL EFFICACY}

\section{Basal Cell Carcinoma Outcome Treated with LDE225 Treatment (BOLT) Studies}

In 2014, a phase I open label multicenter doseescalation study was conducted to evaluate the efficacy and tolerability of the novel smoothened inhibitor sonidegib (LDE225). The study was also accompanied by translational research that demonstrated a dose-dependent reduction in GLI1 mRNA expression, explaining the antitumor activity. In the study, 103 patients with advanced solid tumors, including medulloblastoma and BCC, were enrolled. The maximum tolerated dosage (MTD) was $800 \mathrm{mg}$ once daily or $250 \mathrm{mg}$ twice daily. Overall, 16 patients with BCC and 9 patients with medulloblastoma were included in the study population. Sonidegib was well tolerated, with common grade 1-2 adverse events (AEs), including muscle spasms, increase in the serum creatine phosphokinase (CPK) levels, dysgeusia, gastrointestinal symptoms, and alopecia, occurring in $>10 \%$ of patients. Grade 3-4 AEs occurred in $<5 \%$ of patients and included weight loss, hyperbilirubinemia, and asthenia. The main dose-limiting toxicity (DLT) of reversible grade $3-4$ serum CPK elevation, observed 3 and 6 weeks from the baseline, was at a dosage higher than the MTD in $18 \%$ of patients. Moreover, 6/16 (37.5\%) patients with BCC and 3/9 (33\%) patients with medulloblastoma achieved objective tumor responses [22]. Based on the clinical and histological regression of BCCs, a phase II multicenter randomized study [basal cell carcinoma outcome treated with LDE225 treatment (BOLT)] was conducted. Eligible patients had a World Health Organization (WHO) performance status grade of $0-2$ and histologically confirmed laBCC not amenable to curative surgery or radiation or mBCC. Patients were randomized to receive once-daily oral sonidegib $200 \mathrm{mg}(n=79)$ or $800 \mathrm{mg}(n=151)$ on a continuous dosing schedule, with treatment continued until progressive disease, intolerable toxicity, withdrawal of consent, or death. Dose interruptions for $\leq 21$ days or dose reductions were allowed for treatment-related toxicity. The primary endpoint of the study was the objective response rate (ORR), assessed in the primary analysis with data collected up to 6 months after randomization of the last patient. Patients with laBCCs were assessed using a very restrictive tool called modified response evaluation criteria in solid tumors (mRECIST). The median follow-up was 13.9 months. In the primary efficacy analysis, 20/55 (36\%, 95\% CI 24-50) patients receiving $200 \mathrm{mg}$ sonidegib and 39/116 (34\%, 95\% CI 25-43) receiving $800 \mathrm{mg}$ sonidegib achieved an objective response. Treatment discontinuation was observed in $22 \%$ and $54 \%$ of patients in the $200 \mathrm{mg}$ and $800 \mathrm{mg}$ groups, respectively. Grade 3-4 raised creatine kinase and lipase concentration were the AEs most frequently observed [23] (Table 2). Updated safety and efficacy data from 12-month analysis confirmed sonidegib durable response; disease control rates (percentage of complete responses, partial responses, and stable disease), from the first analysis to 12-month follow-up, improved from $90.9 \%$ to $92.4 \%$ with sonidegib $200 \mathrm{mg}$ and from $81.3 \%$ to $85.9 \%$ with sonidegib $800 \mathrm{mg}$. Furthermore, the safety profile remained similar to the previous study, and almost every patient experienced one or more adverse events [28]. At the 18-month cut-off date, $56 \%$ (95\% CI 43-68) of patients receiving sonidegib $200 \mathrm{mg}$ once daily achieved ORR according to mRECIST criteria with a median time for tumor response of 4 months [29]. In the 30-month analysis, the ORRs for the approved dosage of $200 \mathrm{mg}$ sonidegib were $71.2 \%$ in laBCC patients and $23 \%$ in mBCC patients. Tumor responses were durable, with a median duration of response of 15.7 months in laBCC patients and 18.1 months in mBCC patients. Five patients with laBCC and three with $\mathrm{mBCC}$ in the 200-mg arm died. Sonidegib $200 \mathrm{mg}$ continued to have a better safety profile than $800 \mathrm{mg}$, with lower rates of grade $3 / 4$ adverse events (43.0\% versus $64.0 \%)$ and adverse events leading to discontinuation (30.4\% versus $40.0 \%$ ) [30]. In 2019, Dummer et al. confirmed the long-term efficacy and safety of sonidegib with a 42-month analysis of 
Table 2 Response rates reported in primary analysis (BOLT study) [23]

\begin{tabular}{|c|c|c|c|c|}
\hline & $\begin{array}{l}200 \mathrm{mg} \text { sonidegib } \\
\text { laBCC: } 42\end{array}$ & $\begin{array}{l}800 \mathrm{mg} \text { sonidegib } \\
\text { laBCC: } 93\end{array}$ & $\begin{array}{l}200 \mathrm{mg} \text { sonidegib } \\
\text { mBCC: } 13\end{array}$ & $\begin{array}{l}800 \mathrm{mg} \text { sonidegib } \\
\text { mBCC: } 23\end{array}$ \\
\hline ORR\% (95\% CI) & $43 \%(28-59)$ & $38 \%(28-48)$ & $15 \%(2-45)$ & $17 \%(5-39)$ \\
\hline CR\% & $5 \%$ & 0 & 0 & 0 \\
\hline $\begin{array}{l}\text { Duration of response } \\
\text { (median, months) }\end{array}$ & Not reached & Not reached & Not reached & 8.3 (not estimable) \\
\hline $\begin{array}{l}\text { Progression-free survival } \\
\text { (median, months) }\end{array}$ & Not reached & Not reached & 13.1 & 7.6 \\
\hline $\begin{array}{l}\text { Time to tumor response } \\
\text { (median, months) }\end{array}$ & 3.9 & 3.7 & 4.6 & 1 \\
\hline
\end{tabular}

Table 3 Response rates reported in the 42-month follow-up BOLT study [31]

\begin{tabular}{|c|c|c|c|c|}
\hline & $\begin{array}{l}200 \mathrm{mg} \text { sonidegib } \\
\text { laBCC: } 42\end{array}$ & $\begin{array}{l}800 \mathrm{mg} \text { sonidegib } \\
\text { laBCC: } 128\end{array}$ & $\begin{array}{l}200 \mathrm{mg} \text { sonidegib } \\
\text { mBCC: } 13\end{array}$ & $\begin{array}{l}800 \text { mg sonidegib } \\
\text { mBCC: } 23\end{array}$ \\
\hline ORR\% (95\% CI) & $56.1(43.3-68.3)$ & $46.1(37.2-55.1)$ & $7.7(0.2-36.0)$ & $17.4(5.0-38.8)$ \\
\hline CR\% & 4.5 & 1.6 & 0 & 0 \\
\hline $\begin{array}{l}\text { Duration of response } \\
\text { (median, months) }\end{array}$ & 26.1 & 23.3 & 24 & Not estimable \\
\hline $\begin{array}{l}\text { Progression-free survival } \\
\text { (median, months) }\end{array}$ & 22.1 & 24.9 & 13.3 & Not estimable \\
\hline $\begin{array}{l}\text { Time to tumor response } \\
\text { (median, months) }\end{array}$ & 4 & 3.8 & 9.2 & 1 \\
\hline
\end{tabular}

the randomized BOLT study [31] (Table 3). At the time of study completion, $11 \quad(4.8 \%)$ patients remained on study treatment: $6(7.6 \%)$ and $5(3.3 \%)$ in the $200 \mathrm{mg}$ and $800 \mathrm{mg}$ groups, respectively. ORR observed for patients with laBCC was $56.1 \%$ (95\% CI $43.3-68.3 \%)$ and $46.1 \%$ (95\% CI 37.2-55.1) for the $200 \mathrm{mg}$ and $800 \mathrm{mg}$ groups, respectively; instead, in mBCC patients, lower values were observed $(7.7 \%$ and $17.4 \%$ for the $200 \mathrm{mg}$ and $800 \mathrm{mg}$ groups, respectively). The proportion of patients who discontinued study treatment because of AEs or patients' decision was higher in the $800 \mathrm{mg}$ group compared with the $200 \mathrm{mg}$ group, whereas discontinuations due to disease progression were more frequent in the $200 \mathrm{mg}$ group.

\section{Other Studies Evaluating Sonidegib Efficacy}

The safety of sonidegib was also confirmed by a phase I multicenter single-dose study evaluating the pharmacokinetics of $800 \mathrm{mg}$ oral dose sonidegib in subjects with hepatic impairment. Overall, sonidegib exposures were similar or decreased, and it was generally well tolerated, not requiring any dose adjustment even in patients with severe hepatic impairment [32]. Based on the pharmacokinetics of sonidegib, another phase I study investigated the effect of 
a proton pump inhibitor (esomeprazole) on the oral absorption of $\mathrm{Hh}$ inhibitor [33]. Results suggested only a modest reduction of sonidegib absorption and no drug-drug interaction was observed. There have been indications that the upregulation of the phosphoinositol-3-kinase (PI3K) pathway can be a potential mechanism of resistance to sonidegib, inducing the activation of transcription of GLI genes [34, 35]. Preclinical work in patients with medulloblastoma revealed that the concurrent use of smoothened and PI3K inhibition delays sonidegib resistance. Thereby, a clinical trial investigating combined hedgehog and PI3K inhibition in BCC patients was explored, using sonidegib (200 $\mathrm{mg} /$ day) and buparlisib ( $80 \mathrm{mg}$ daily), a pan-PI3K inhibitor, for 28-day cycles. Seven patients were evaluated for ORR, and ten patients were evaluated for AEs; although one patient presented an ORR $14.3 \%$, the majority of them experienced stable disease or partial response with high number of adverse events. With the two drugs combination, all AEs were anticipated and resolved only with dose reduction or discontinuation from the two drugs study [36]. The efficacy of sonidegib was also studied in patients with laBCCs resistant to vismodegib treatment; the authors found that patients that were previously resistant to treatment with vismodegib similarly present resistance to treatment with sonidegib due to a subset of acquired mutations in the drug target SMO [37]. In a recent randomized trial, Lear et al. evaluated the efficacy of sonidegib in patients with nevoid basal cell carcinoma syndrome (Gorlin syndrome). Seven patients treated with $400 \mathrm{mg} /$ day sonidegib for 12 weeks completed the study; at week 16, complete clinical clearance was observed in three of seven (43\%) patients receiving sonidegib, while the remaining four patients experienced at least moderate clinical clearance. Overall, all patients receiving sonidegib $400 \mathrm{mg}$ experienced complete or partial clearance of $\mathrm{BCC}$, and no patient receiving sonidegib had worsening of the target BCC [38].

\section{Use of Sonidegib in Gorlin Syndrome}

The efficacy of sonidegib in Gorlin syndrome had been previously demonstrated in the BOLT trial [30], in which eight patients in the $800 \mathrm{mg}$ arm ( $n: 13)$ experienced complete remission of the BCCs; the adverse events rate (88\%) was similar to that observed in patients with sporadic BCCs. Interestingly, the use of sonidegib formulated as a cream for topical application was also investigated in eight patients with Gorlin syndrome (BCCs: 27) [39]. Of 13 BCCs in these individuals treated with $0.75 \%$ LDE225 topical cream, three BCCs had a complete response, nine BCCs had a partial response, while only one BCC failed to demonstrate any clinical response. However, trials with larger sample size did not reproduce the same efficacy with topical sonidegib, maybe due to the limited drug penetration of the cutaneous barrier [40]. In patients with BCC, characteristic features of BCC on high-resolution skin imaging techniques decreased or disappeared completely during treatment with sonidegib. Imaging revealed a loss of the peripheral rim surrounding the tumor nodules, loss of peripheral palisading of tumor cells, and an increase in fibrotic tissue [41]. In literature, there are no head-to-head randomized controlled trials comparing sonidegib with vismodegib, the other hedgehog inhibitor firstly approved for the treatment of locally advanced and metastatic basal cell carcinoma. To date, only joint expert opinions summarizing clinical and pharmacological profiles of the two drugs, based on published data and data from clinical experience, have been published [42-44].

\section{SAFETY, TOLERABILITY, AND ADVERSE EVENTS}

Side effects from SMO inhibitors are very common and can be significant. Adverse events frequently represent a limiting factor in continuous treatment, and dose adjustments or different schemes to avoid discontinuation and increase patients compliance are often required $[45,46]$. In the initial BOLT study, $>10 \%$ of patients experienced treatment-related mild 
(grade 1-2) adverse events, including muscle spasms (49\%), alopecia (43\%), dysgeusia (38\%), nausea (33\%), raised blood creatine kinase (CK) levels (29\%), fatigue (29\%), decreased weight (27\%), diarrhea (24\%), decreased appetite (19\%), myalgia (19\%), headache (15\%), and arthralgia (13\%). Grade 3-4 adverse events occurred in $30 \%$ of patients receiving sonidegib $200 \mathrm{mg}$ once daily, with the most frequently $(\geq 2 \%)$ reported events being elevated CK (4\% grade 3 ; $3 \%$ grade 4 ), increased lipase (5\%; all grade 3), hypertension, asthenia, and muscle spasms (all 3\%; all grade 3). Secondary malignancies (three squamous cell carcinoma, one malignant melanoma, and one prostate cancer) were also reported in $6 \%$ of patients. No deaths due to toxicity were reported [22]. Dose reduction occurred in $17(17 \%)$ patients, mostly receiving $800 \mathrm{mg}$ sonidegib dose, and 20 (19\%) patients discontinued treatment for adverse events, in particular 14 of 20 were associated with elevated creatine kinase (CK) levels and myalgia. No renal dysfunction was reported, and no significant changes in creatine kinasemyocardial B isoenzyme, suggestive of cardiac muscle injury, were noted [22]. At 12-month follow-up [28], fewer adverse events occurred in patients treated with $200 \mathrm{mg}$ sonidegib; $6 \%$ and $13 \%$ in the $200 \mathrm{mg}$ and $800 \mathrm{mg}$ groups, respectively, experienced severe adverse events such as raised creatine kinase and lipase concentration. The most frequently reported AEs at a longer follow-up remained unchanged, and grade 3-4 AEs occurred less frequently with sonidegib $200 \mathrm{mg}(43.0 \%)$ than with $800 \mathrm{mg}$ (64.0\%); increased CK was always the most frequent adverse event. In 30\% of cases, laboratory exams in patients treated with sonidegib showed increased serum creatinine (92\%), hypercholesterolemia (71\%), increased serum CK (57\%), hyperglycemia (47\%), increased lipase (39\%), and decreased magnesium (32\%). Commonly reported grade 3-4 laboratory abnormalities were increased lipase (11\%), increased serum CK (6\%), hyperglycemia (4\%), hyperkalemia (4\%), increased alanine transaminase (ALT) (3\%), and increased aspartate aminotransferase (AST) (3\%), reported in $<2 \%$ of patients [30].

\section{Management of Adverse Events}

Usually, the majority of adverse events appear after a few weeks from the beginning of treatment with HPIs, so patients must be informed and educated to better manage these adverse events and avoid treatment discontinuation. A complete medical examination (blood test, presence of comorbidities, and other skin complaints) should be carried out before starting treatment. Regarding sonidegib, serum CK levels and renal function should be tested before starting treatment and monitored periodically during treatment. Moreover, the management of the typical adverse effects of HPIs, such as muscle spasms, dysgeusia, and alopecia, is of great importance to prolong treatment duration and avoid treatment discontinuation. Lacouture et al. [47] constructed an algorithm to manage the most frequent adverse events. Muscle spasms is one of the first adverse events appearing; they are more severe at night and usually located on the lower legs. Patients should maintain adequate hydration and gentle physical activity while taking sonidegib. The risk and severity of muscle spasms could be reduced with the use of magnesium supplementation, muscle relaxants, analgesics, or narcotics. Pharmacological treatments may include calcium channel blockers, such as amlodipine, diltiazem, and verapamil, and nerve stabilizers, such as gabapentin or pregabalin. When AEs become intolerable, treatment should be interrupted. Ageusia and dysgeusia are also among the adverse events presenting more frequently. They alter patients' quality of life, causing anorexia and depression. Identification of more pleasant food for the patient as well as a dietitian referral can reduce these problems. Alopecia with diffuse loss of hair density could also be observed; it affects the scalp, but also the eyebrows, eyelashes, and beard. The use of minoxidil $2-5 \%$ can be helpful [48].

\section{PERSPECTIVES AND CONCLUSIONS}

This evaluation of the clinical efficacy and safety profile of sonidegib demonstrated it to be 
very promising in patients with advanced BCCs, like its competitor vismodegib, although the first resulted to be more effective in patients with laBCCs rather than mBCCs. A large proportion of patients reported grade 1-2 adverse events and/or abnormalities in blood exams; fewer severe adverse events were also described. The correct management of side effects could improve patients' health-related quality of life, thus reducing treatment discontinuation. Experiencing regimen adjustment with potential treatment holiday as well as novel approaches for side profile management might provide options for improving the tolerability of this therapy [49-51]. Moreover, positive results from trials conducted in patients with Gorlin syndrome showed the possibility of using this HPI not only for treatment of one laBCC but also for cancer chemoprevention. Vismodegib is the first approved HPI used in the treatment of advanced BCCs [12]. Although the two agents act on the same pathway and have similar indications, there are currently no randomized controlled trials comparing sonidegib with vismodegib, and no evidence-based recommendations to choose between them have been established. To ensure maximum benefit from therapy, better knowledge of the drug to give patients correct instructions and a strict followup are required. As sonidegib is a novel drug, there are no studies in literature reporting case series or single-center experiences that could be useful to confirm the efficacy demonstrated in all the trials described above. Further studies of real-world experiences are needed to better understand the correct management of the drug, alternative dosing regimens, and differences with the other HHI.

\section{ACKNOWLEDGEMENTS}

Funding. No funding or sponsorship was received for this study or the publication of this article.

Authorship. All named authors meet the International Committee of Medical Journal Editors (ICMJE) criteria for authorship for this manuscript, take responsibility for the integrity of the work as a whole, and have given final approval to the version to be published.

Disclosures. Alessia Villani, Claudia Costa and Massimiliano Scalvenzi have nothing to disclose. Gabriella Fabbrocini is a member of the journal's Editorial Board.

Compliance with Ethics Guidelines. This article is based on previously conducted studies and does not contain human participants or animals performed by any of the authors.

Data Availability. Data sharing is not applicable to this article as no datasets were generated or analyzed during the current study.

Open Access. This article is licensed under a Creative Commons Attribution-NonCommercial 4.0 International License, which permits any non-commercial use, sharing, adaptation, distribution and reproduction in any medium or format, as long as you give appropriate credit to the original author(s) and the source, provide a link to the Creative Commons licence, and indicate if changes were made. The images or other third party material in this article are included in the article's Creative Commons licence, unless indicated otherwise in a credit line to the material. If material is not included in the article's Creative Commons licence and your intended use is not permitted by statutory regulation or exceeds the permitted use, you will need to obtain permission directly from the copyright holder. To view a copy of this licence, visit http://creativecommons.org/licenses/by$\mathrm{nc} / 4.0 /$.

\section{REFERENCES}

1. Cameron MC, Lee E, Hibler BP. Basal cell carcinoma: epidemiology; pathophysiology; clinical and histological subtypes; and disease associations. J Am Acad Dermatol. 2019;80(2):303-17.

2. Mohan SV, Chang ALS. Advanced basal cell carcinoma: epidemiology and therapeutic innovations. Curr Dermatol Rep. 2014;3(1):40-5. 
3. Telfer NR, Colver GB, Morton CA, British Association of Dermatologists. Guidelines for the management of basal cell carcinoma. Br J Dermatol. 2008;159(1):35-48.

4. Villani A, Fabbrocini G, Cappello M, Costa C, Scalvenzi M. Real-Life effectiveness of vismodegib in patients with metastatic and advanced basal cell carcinoma: characterization of adverse events and assessment of health-related quality of life using the Dermatology Life Quality Index (DLQI) test. Dermatol Ther (Heidelb). 2019;9(3):505-10.

5. Migden MR, Chang AL, Dorox L, et al. Emerging trends in the treatment of advanced basal cell carcinoma. Cancer Treat Rev. 2018;64:1-10.

6. Trakatelli M, Morton C, Nagore E, et al. Update of the European guidelines for basal cell carcinoma management. Eur J Dermatol. 2014;24(3):312-29.

7. Lear JT, Corner C, Dziewulski P, et al. Challenges and new horizons in the management of advanced basal cell carcinoma: a UK perspective. Br J Cancer. 2014;111:1476-81.

8. Scalvenzi M, Villani A, Mazzella C, Cappello M, Salvatores GD, Costa C. Vismodegib treatment in a HIV positive patient on antiretroviral therapy. Indian J Dermatol Venereol Leprol. 2018;84: 758-60.

9. Leavitt E, Lask G, Martin S. Sonic hedgehog pathway inhibition in the treatment of advanced basal cell carcinoma. Curr Treat Options Oncol. 2019;20(11):84.

10. Carpenter RL, Ray H. Safety and tolerability of sonic hedgehog pathway inhibitors in cancer. Drug Saf. 2019;42(2):263-79.

11. Amakye D, Jagani $Z$, Dorsch M. Unraveling the therapeutic potential of the Hedgehog pathway in cancer. Nat Med. 2013;19(11):1410-22.

12. Genentech (2015) Erivedge ${ }^{\circledR}$ (vismodegib) capsules, for oral use: US pre-scribing infomation. https:// www.erivedge.com/. Accessed 13 Jan 2016

13. European Medicines Agency (2015) Erivedge 150 mg hard capsules: summary of product characteristics. https://www.ema.europa.eu/. Accessed 13 Jan 2016

14. Novartis (2015) Odomzo ${ }^{\circledR}$ (sonidegib) capsules, for oral use: US prescribing infomation. www.odomzo. com/. Accessed 13 Jan 2015

15. European Medicines Agency (2015) Odomzo ${ }^{\circledR} 200$ mg hard capsules: summary of product characteristics. https://www.ema.europa.eu/. Accessed 13 Jan 2016
16. Dahmane N, Lee J, Robins P, Heller P, Ruiz I, Altaba A. Activation of the transcription factor Gli1 and the Sonic hedgehog signalling pathway in skin tumours. Nature. 1997;389:876-81.

17. Epstein EH. Basal cell carcinomas: attack of the hedgehog. Nat Rev Cancer. 2008;8:743-54.

18. Aszterbaum M, Rothman A, Johnson RL, et al. Identification of mutations in the human PATCHED gene in sporadic basal cell carcinomas and in patients with the basal cell nevus syndrome. J Invest Dermatol. 1998;110:885-8.

19. D'Amato C, Rosa R, Marciano R, et al. Inhibition of hedgehog signalling by NVP-LDE225 (erismodegib) interferes with growth and invasion of human renal cell carcinoma cells. Br J Cancer. 2014;111(6): 1168-79.

20. Burness CB. Sonidegib: first global approval. Drugs. 2015;75(13):1559-666.

21. Zollinger M, Lozac'h F, Hurh E, et al. Absorption, distribution, metabolism, and excretion (ADME) of (1)(4)C-sonidegib (LDE225) in healthy volunteers. Cancer Chemother Pharmacol. 2014;74(1):63-75.

22. Rodon J, Tawbi HA, Thomas AL, et al. A phase I, multicenter, open-label, first-in-human, dose-escalation study of the oral smoothened inhibitor sonidegib (LDE225) in patients with advanced solid tumors. Clin Cancer Res. 2014;20(7):1900-9.

23. Migden MR, Guminski A, Gutzmer R, et al. Treatment with two different doses of sonidegib in patients with locally advanced or metastatic basal cell carcinoma (BOLT): a multicentre, randomised, double-blind phase 2 trial. Lancet Oncol. 2015;16(6):716-28.

24. Goel V, Hurh E, Stein A, et al. Population pharmacokinetics of sonidegib (LDE225), an oral inhibitor of hedgehog pathway signaling, in healthy subjects and in patients with advanced solid tumors. Cancer Chemother Pharmacol. 2016;77(4):745-55.

25. Chen L, Silapunt S, Migden MR. Sonidegib for the treatment of advanced basal cell carcinoma: a comprehensive review of sonidegib and the BOLT trial with 12-month update. Future Oncol. 2016;12(18):2095-105.

26. Zhou J, Hurth E, Emotte C et al (2014) Evaluation of CYP3A4 endogenous biomarkers in a sonidegib drug-drug interaction study with rifampicin and ketoconazole in healthy subjects. In: American society for clinical pharmacology and therapeutics annual meeting 
27. Burness CB, Scott LJ. Sonidegib: a review in locally advanced basal cell carcinoma. Target Oncol. 2016;11(2):239-46.

28. Dummer R, Guminski A, Gutzmer R, et al. The 12-month analysis from Basal Cell Carcinoma Outcomes with LDE225 Treatment (BOLT): a phase II, randomized, double-blind study of sonidegib in patients with advanced basal cell carcinoma. J Am Acad Dermatol. 2016;75(1):113-125.e5.

29. Lear J, Guminski A, Gutzmer R (2015) A phase 2, randomized, double-blind study of sonidegib (LDE225) in patients with advanced basal cell carcinoma: the BOLT 18-month analysis [abstract]. In: 24th EADV congress

30. Lear JT, Migden MR, Lewis KD, et al. Long-term efficacy and safety of sonidegib in patients with locally advanced and metastatic basal cell carcinoma: 30-month analysis of the randomized phase 2 BOLT study. J Eur Acad Dermatol Venereol. 2018;32(3):372-81.

31. Dummer R, Guminksi A, Gutzmer R, et al. Longterm efficacy and safety of sonidegib in patients with advanced basal cell carcinoma: 42-month analysis of the phase II randomized, double-blind BOLT study. Br J Dermatol. 2019. https://doi.org/ 10.1111/bjd.18552.

32. Horsmans Y, Zhou J, Liudmila M. Effects of mild to severe hepatic impairment on the pharmacokinetics of sonidegib: a multicenter, open-label parallelgroup study. Clin Pharmacokinet. 2018;57(3): 345-54.

33. Zhou J, Quinlan M, Glenn K. Effect of esomeprazole, a proton pump inhibitor on the pharmacokinetics of sonidegib in healthy volunteers. Br J Clin Pharmacol. 2016;82(4):1022-9.

34. Gonnissen A, Isebaert S, Haustermans K. Targeting the Hedgehog signaling pathway in cancer: beyond smoothened. Oncotarget. 2015;6:13899-913.

35. Buonamici S, Williams J, Morrissey M, Wang A, Guo R, Vattay A, et al. Interfering with resistance to smoothened antagonists by inhibition of the PI3K pathway in medulloblastoma. Sci Transl Med. 2010;2:51ra70.

36. Tran DC, Moffat A, Brotherton R, Pague A, Zhu GA, Chang ALS. An exploratory open-label, investigator-initiated study to evaluate the efficacy and safety of combination sonidegib and buparlisib for advanced basal cell carcinomas. J Am Acad Dermatol. 2018;78(5):1011-1013.e3.

37. Danial C, Sarin KY, Oro AE, Chang AL. An investigator-initiated open-label trial of sonidegib in advanced basal cell carcinoma patients resistant to vismodegib. Clin Cancer Res. 2016;22(6):1325-9.

38. Lear JT, Hauschild A, Stockfleth E, Squittieri N, Basset-Seguin N, Dummer R. Efficacy and safety of sonidegib in adult patients with nevoid basal cell carcinoma syndrome (gorlin syndrome): results from a phase 2 , double-blind randomized trial. Clin Cosmet Investig Dermatol. 2020;13:117-21.

39. Skvara H, Kalthoff F, Meingassner JG, et al. Topical treatment of basal cell carcinomas in nevoid basal cell carcinoma syndrome with a smoothened inhibitor. J Invest Dermatol. 2011;131:1735-44.

40. Pharmaceuticals N To evaluate the safety, local tolerability, PK and PD of LDE225 on sporadic superficial and nodular skin basal cell carcinomas (sBCC). www.clinicaltrials.gov

41. Maier T, Kulichova D, Ruzicka T, et al. Noninvasive monitoring of basal cell carcinomas treated with systemic hedgehog inhibitors: pseudocysts as a sign of tumor regression. J Am Acad Dermatol. 2014;71(4):725-30.

42. Dummer R, Ascierto PA, Basset-Seguin N, et al. Sonidegib and vismodegib in the treatment of patients with locally advanced basal cell carcinoma: a joint expert opinion. J Eur Acad Dermatol Venereol. 2020. https://doi.org/10.1111/jdv. 16230 (published online ahead of print, 2020 Jan 28).

43. Xie P, Lefrançois P. Efficacy, safety, and comparison of sonic hedgehog inhibitors in basal cell carcinomas: a systematic review and meta-analysis. J Am Acad Dermatol. 2018;79(6):1089-1100.e17. https:// doi.org/10.1016/j.jaad.2018.07.004.

44. Odom D, Mladsi D, Purser M, et al. A matchingadjusted indirect comparison of sonidegib and vismodegib in advanced basal cell carcinoma. J Skin Cancer. 2017;2017:6121760. https://doi.org/10. $1155 / 2017 / 6121760$.

45. Scalvenzi M, Costa C, Cappello M, Villani A. Reply to Woltsche $\mathrm{N}$. et al. Managing adverse effects by dose reduction during routine treatment of locally advanced basal cell carcinoma with the hedgehog inhibitor vismodegib: a single-centre experience. J Eur Acad Dermatol Venereol. 2019;33(4): e145-e147147.

46. Ramelyte E, Amann VC, Dummer R. Sonidegib for the treatment of advanced basal cell carcinoma. Expert Opin Pharmacother. 2016;17(14):1963-8. https://doi.org/10.1080/14656566.2016.1225725.

47. Lacouture ME, Dréno B, Ascierto PA, et al. Characterization and management of hedgehog pathway inhibitor-related adverse events in patients with 
advanced basal cell carcinoma. Oncologist. 2016;21(10):1218-29.

48. Chen L, Aria AB, Silapunt S, Lee HH, Migden MR. Treatment of advanced basal cell carcinoma with sonidegib: perspective from the 30-month update of the BOLT trial. Future Oncol. 2018;14(6):515-25.

49. Villani A, Megna M, Fabbrocini G, et al. Long-term efficacy of vismodegib after its withdrawal and patients' health-related quality of life using the
Dermatology Life Quality Index (DLQI). Dermatol Ther (Heidelb). 2019;9(4):719-24.

50. Jain S, Song R, Xie J. Sonidegib: mechanism of action, pharmacology, and clinical utility for advanced basal cell carcinomas. Onco Targets Ther. 2017;10:1645-53.

51. Collier NJ, Ali FR, Lear JT. The safety and efficacy of sonidegib for the treatment of locally advanced basal cell carcinoma. Expert Rev Anticancer Ther. 2016;16(10):1011-8. 